sciendo Порівняльна професійна педагогіка 8(4)/2018 Comparative Professional Pedagogy 8(4)/2018

DOI: $10.2478 /$ rpp-2018-0053

Postgraduate Student, INNA ROMANIUK

Khmelnytskyi National University, Ukraine

Address: 11 Instytutska St., Khmelnytskyi, 29016, Ukraine

E-mail: inachkawhite@gmail.com

\title{
TRAINING SOCIAL EDUCATORS TO ORGANIZE CULTURAL AND LEISURE ACTIVITIES: BRITISH AND UKRAINIAN EXPERIENCE
}

\begin{abstract}
The article analyzes the process of training social educators how to organize cultural and leisure activities. It was specified that analysis and thorough study of British experience was a fundamental source required to define relevant strategies and areas to solve the problem of training social educators to organize cultural and leisure activities. The article reveals the peculiarities of social educators' scientific training, examines the ways of supporting and developing these specialists in the UK and Ukraine. It was noted that conceptual foundations of these specialists' training to organize cultural and leisure activities should be justified taking into account the following components: the level of their spiritual development, life experience, active social and cultural activities, continuing education, the principles of comparative pedagogy, etc. It was concluded that professional training of social educators in foreign experience was similar in the fact that complex functions of recreational, leisure, cultural potential were realized only by specialists who obtained university education and also received additional knowledge in the field of social work, social pedagogy and other related disciplines. It was specified that the complexity of training social educators in British experience consists in the fact that these specialists should have the knowledge of various issues: from the principles of social and cultural state policy, general organization of social security system, specificity of cultural and leisure infrastructure functioning, demographic peculiarities to relevant methods of working with different gropus of population. It was clarified that prospects for further research should be aimed at analyzing educational scientific and methodological recommendations of international experience in training social educators.
\end{abstract}

Keywords: leisure, spare time, leisure activities, cultural and leisure activities, school counsellor, organizer, theoretical and practical experience, the UK, Ukraine.

\section{INTRODUCTION}

The rapid entry of Ukraine into the European Higher Education Area and the development of spiritual and national priorities have led to actualization of reform of the national education, in particular in the context of organization of cultural and leisure activities. Therefore, higher education institutions should aim to train such specialists who can contribute to spiritual, cultural and moral development of the younger generation and provide children and young people with socially positive leisure. This aim should be achieved taking into account the principles of the Bologna Declaration of the European Union, the Laws of Ukraine "On Education", "On Higher Education", "On Culture", "On Social Work with Families, Children and Youth".

It must be noted that changes in the national higher education caused by the Bologna Declaration have contributed to the emergence of new approaches, goals and objectives of organization of cultural and leisure activities. 
The analysis of documentary and literary sources and the study of Ukrainian experience in training social educators in higher education institutions show that there is a number of problems that should be addressed. They include scientific justification of conceptual principles in professional training of social educators as leisure organizers, quality assurance of specialis training in the context of leisure activities, update of legal, organizational and pedagogical and scientific and methodological support, etc.

\section{THE AIM OF THE STUDY}

The aim of the article consists in defining strategies for ensuring professional development of future social educators in organization of cultural and leisure activities taking into account the innovative ideas of British experience.

\section{THEORETICAL FRAMEWORK AND RESEARCH METHODS}

The problem of training specialists able to organize and manage leisure activities of children was studied by many scholars. Some ways of training future educators to organize leisure activities were described by Yu. Bardshevska, I. Boicheva, O. Holika, N. Yaremenko, L. Zaremba et al. General problems of organizing cultural and leisure activities and children's leisure were defined in a range of fundamental researches. V. Bocheliuk and N. Yaremenko addressed the problem cultural and leisure activities and leisure organization. I. Petrova amd A. Ryzhanova considered professional training of specialists in the social sphere abroad, including cultural and leisure activities. Theoretical and methodological principles of training social educators for professional activities were highlighted by O. Bezpalko, A. Kapska, O. Karpenko, S. Kharchenko, L. Mishchyk, N. Oleksiuk, V. Polishchuk, Zh. Petrochko, S. Savchenko, R. Vainoli et al.

Foreign scholars explain the relevance of studying pedagogy of leisure with the crisis of culture and morality, social non-adaptability, alienation and infantilism of most of the population, contradictions and deformations in spiritual life, inconsistency between the objectively developed pedagogical potential of leisure and the extent of its implementation, an unjustified advantage of entertainment over education, which makes it impossible to solve educational and sociocultural tasks. Some foreign scholars believe that these disadvantages can be effectively eliminated provided that pedagogy of leisure is being developed and aimed at motivating the invidiual to spend his/her spare time efficiently. The problems of leisure and leisure specialists' training were considered by many foreign scholars such as A. Barber (1989), R. Bauer (1959), G. Chick (1998), F. Colater (1997), T. Kiseleva (2000), Yu. Streltsov (2002), G. Torkildsen (1983) et al.

The following research methods contributed to solving the aim of the study: theoreical and comparative analysis, generalization of foreign scientific literature, systematization and definition of conceptual principles of the research.

\section{RESULTS}

Presently, cultural and leisure activities occupy a significant place in the education process. The existing diversity of their forms makes it possible to cultivate a harmonious individual. Thus, readiness to organize such activities is a fundamental component of future social educators' professional competency. Its distinctive feature consists in the ability to organize the education process efficiently, to employ pedagogical principles of gaming activities, which in turn contributes to personal development of pupils.

Over the past few decades, the paradigm of sociocultural education has changed significantly due to the orientation towards a fundamentally new understanding of culture and its role in the education system. As rightly noted by Javier Perez de Cuellar in his opening speech at the World Commission on Culture and Development (1993), education 
sciendo Порівняльна професійна педагогіка 8(4)/2018 Comparative Professional Pedagogy 8(4)/2018

links culture and development. Development is possible only if education and culture together cultivate the personality of the individual rather then his/her social and professional potential. Any developmental activity must be harmoniuosly combined with culture (Kiseleva, \& Chizhikov, 2000).

The modern theory of leisure is characterized by interdisciplinarity based on the findings of many sciences, namely psychology, pedagogy, sociology, philosophy, geography, economics. Since the second half of the 20th century, leisure has been, however, viewed as an independent branch of knowledge, which deals with the role of spare time in life, its content characteristics and impact on personality development. Before considering theoretical principles of leisure in foreign contexts, it should be noted that in Ukraine the concept of "cultural and leisure activities" is understood as the use of free time to enhance one's creativity, culture, etc. In contrast, cultural and leisure activities in foreign contexts are perceived as follows: "leisure industry", "entertainment and recreation" (the USA, the UK), "leisure time" (Germany), "animation" (Italy, Turkey, France). Such terms are historically predetermined and depend on social, political, cultural, and economic policies of a particular country (Petrova, 2005).

Modern foreign systems of leisure define the concept of leisure in different ways. In particular, it is considered by foreign scholars as synonymous with progress and liberalization (J. Dumazedier, J. Pronovost et al.); social value that is necessary for fullfledged development of personality (N. Anderson, T. O'Brien, M. Carter et al.); the meaning of life, a universal value (M. Kaplan et al.); relaxation (M. Harington, R. Krauss et al.); modern embodiment of freedom (D. Volpicelli); compensation for something (J. Friedman, E. Mayo et al.); free time when one is not working or attending other duties (J. Kelly) (Barberm 1989; Bauer, 1959; Coalter, 1997; Ariarkiy, 2000).

Professional training of leisure specialists overseas is carried out through special courses in educational institutions. Personnel policy is decentralized and is subject to education authorities (public, municipal, regional ones) and, therefore, has its differences (Mandi, 2002). We believe that Ukrainian scholars and practitioners should analyze the problems in foreign science, which directly influence educational activities, since the consistency of the education process with the latest scientific advances in leisure sector is an important factor in determining education policy.

Therefore, foreign countries pay considerable attention to the integration of theory and practice, namely theoretical courses offered in educational institutions and practical ones provided in sociocultural institutions, residential institutions and social work agencies. This is a necessary condition for professionalization of the specialist. When practical training focuses only on updating existing methodological documentation, rather than introducing novel practical methods, such a model of training does not ensure the achievement of expected outcomes. Practical training develops students' motivation towards self-development, self-realization and personal growth. In general, training should be based on such principles as consistency; specilization of scientific courses; optimal balance of general, special and specialized courses; rational distribution of academic hours (optional and compulsory classes, individual and practical activities, creative activities, self-directed study) (Petrova, 2005).

In the UK, there is an extensive network of specialist courses for training social educators to work with children and youth in community centers and leisure facilities. There are 3- or 6-month courses of youth leaders, which are aimed at improving the 
sciendo Порівняльна професійна педагогіка 8(4)/2018 Comparative Professional Pedagogy 8(4)/2018

qualifications of the individuals with higher education, who work in the Youth Service and intend to deepen their knowledge. Those individuals who complete 1- or 3-year courses are entitled to receive a certificate or diploma of a professional employee of the Service (Pichkar, 2002).

In the UK, a leisure specialist is referred to as "a social worker", "a youthspecialist in the community". J. Torkilstsen (1983) notes that in the country theire is no system of special training for organizing leisure activities, which adversely affects professional training of managers in leisure facilities.

The Institute for the Management of Sport and Physical Acitivity (IMSPA) formed through a merger of the Institute of Sport Recreation Management (ISRM) and the Institute for Sport, Parks and Leisure (ISPAL) in 2011 provides professional training in the leisure sector. The IMSPA consists of many institutes and associations, which offer specialized training in the leisure sector. The Institute of Park and Recreation Administration trains organizers of leisure in parks. The Institute of Municipal Entertainment trains specialists, who organize leisure activities in charity organizations and cultural and leisure municipal facilities. The Association of Recreation Managers trains specialists, who are competent in organizing sports competitions, providing spectators with services, supervising work in bars, cafes, etc. The Institute of Baths and Recreation Management is engaged in designing and constructing swimming pools and sports centers (Torkildsen, 1983, pp. 457-460).

The curricula for youth associations management developed by the UK universities are of great interest. They are divided into the following subject-specific sections: 1) psychological, pedagogical, medical and social principles of youth development; 2) patterns and trends in the development of modern society; 3) principles of youth leadership.

The first group of subjects provide knowledge of psychology and pedagogy of children, adolescents and youth; theory and methodology of youth movements; the Youth Service history. The second group of subjects involves studying the history of public associations development, legal framework for regulation of their activities, social and economic conditions of young people's lives, impact of social institutions on youth, familiarization with the youth policy adopted in the country. The third group of subjects is aimed at applying the acquired knowledge in practice under the lecturer's supervision. Students work in various leisure facilities, community centers, children's and youth associations (Petrova, 2005).

In the UK, despite the multifaceted nature of activities of youth organizations managers, their professional training is a complex, which combines a range of professional knowledge, skills and abilities. It is based on a sociocultural programme for youth, covering all types of youth activities. Therefore, the process of implementing a youth project systematizes theoretical and practical knowledge, stimulates students' interest in a particular kind of professional activity, gives the opportunity to develop theatrical art, oratory skills, organize competitions, club meetings. Thus, the process of acquiring professional knowledge consists if three stages: mastering theoretical fundamentals, studying specialized subjects, acquiring practical experience in youth associations.

In Ukraine, professional training of social educators for organizing cultural and leisure activities is based on a certain system. The network of higher education institutions makes it possible to train specialists with higher education. However, the rapidly changing sociocultural situation and the new ways and priorities in social development urge universities to search for novel teaching methods. It should be noted that every higher 
sciendo Порівняльна професійна педагогіка 8(4)/2018 Comparative Professional Pedagogy 8(4)/2018

education institution has its own scientific and methodological findings, positive experience, vision of prospects in training social educators for work in the leisure sector, unique features, since the education process should be creative and meet individual interest of every student (Slozanska, n.a.).

In the UK, the framework of the Institute of Leisure and Amenity Management organizes seminars and advanced training courses in park administration and recreation. In addition, it provides scientific and methodological support for parks and recreational facilities by preparing and disseminating thematic publications for relevant specialists, organizing lectures and training courses, systematically carrying out research on park and recreational development (Barber, 1989). It must be noted that British scholars view continuing professional development as an effective means of improving leisure practice. This has led to the adoption of professional development programmes in the country, as well as the development of mechanisms for determining the level of professional competency (registration, licensing, certificates, etc.).

In the UK, continuing education of leisure specialists is based on problem-oriented approach rather than subjective or content ones. According to some foreign scholars and practitioners, such an approach is fully justified and is explained by recognition of professional needs of adult students who need to reconsider their acquired skills and renew their knowledge. Therefore, problem-oriented approach allows one to master the methods, which meet the current demands of society, acquire the necessary knowledge and skills. Training programmes involve such forms of activities as courses, seminars, meetings, social and cultural events, conferences, etc. In addition, they allow one to monitor the sociocultural changes occurring in the external environment and the personnel policy and to respond to topical problems in a timely manner.

Continuing education programmes are based on a systematic study of public opinion about the level and quality of leisure activities, assessment of leisure activities in individual areas, offers of leisure services consumers. Thus, an ineffective organization of youth leisure, adolescents and youth's complaints about uninteresting entertainment programmes, leisure specialists' disregard to the needs of the younger generation prove the need to improve the quality of youth leisure (Petrova, 2005). Yet, British scholars indicate that once specialists have gained professional experience, they are reluctant to improve their qualifications. However, when doing so, they risk facing a situation of "incompetency".

Any leisure, social or recreational institution mainly develops due to professional growth of its employees. The source of growth and effective activity of every leisure institution is intellectual potential and practical experience of leisure specialists. The main principles of leisure specialists' professional growth are activity, development, and improvement.

The multifaceted creative, pedagogical nature of leisure activities should adequately determine the structure of professional educational technologies. Consequently, when accumulating ideological, scientific, theoretical and practical ideas of cultural and leisure activities, educational institutions should create optimal conditions for training, which will allow future specialists to achieve professional mastery.

The way students spend their spare time is rather important for their professional training. In the UK, they establish academic student societies, forums, geography clubs, choreography studios, animation clubs, computer clubs, programming clubs, sports sections (Pichkar, 2002). 
sciendo Порівняльна професійна педагогіка 8(4)/2018 Comparative Professional Pedagogy 8(4)/2018

Having analyzed the UK experience in training leisure specialists, it can be concluded that their system education is based on culture-oriented model aimed not only at consuming and trasferring knowledge, but also teaching students how to renew the knowledge in various forms of leisure practice.

This experience can be implemented in Ukraine with the aim to improve professional training of social educators and better prepare them for organizing cultural and leisure activities. It should be emphasized that copying of foreign educational technologies is inappropriate and inefficient, since education is primarily a source of its own culture and uniqueness.

We believe that in Ukraine professional training of social educators is complicated by the lack of initial training in organizing leisure and cultural activities. It mainly involves students' participation in amateur associations, clubs and their organization and implementation of small cultural and leisure events.

\section{CONCLUSIONS}

Therefore, it can be concluded that professional training of social educators in foreign experience is similar in the fact that complex functions of recreational, leisure, cultural potential are realized only by specialists who obtained university education and also received additional knowledge in the field of social work, social pedagogy and other related disciplines.

The complexity of training social educators in British experience consists in the fact that these specialists should have the knowledge of various issues: from the principles of social and cultural state policy, general organization of social security system, specificity of cultural and leisure infrastructure functioning, demographic peculiarities to relevant methods of working with different gropus of population. Social educators must possess professional skills which can solve problems in sociology of culture, pedagogy, psychology, social work. In the UK, the model of training social educators differs from other related fields by its creative character. Therefore, it is important that social educators are able to apply the acquired knowledge in practical situations, synthesize it, solve educationl tasks creatively.

Prospects for further research are aimed at analyzing educational scientific and methodological recommendations of international experience in training social educators.

\section{REFERENCES}

1. Ariarskii, M. A. (2000). Prikladnaia kulturologiia kak oblast nauchnogo znaniia $i$ sotsialnoi praktiki. (Avtoref. diss. d-ra kulturologii). Sankt-Peterburgskii gosudarstvennyi universitet kultury i isskustv, Sankt-Peterburg.

2. Barber, A. (1989). Associations abroad: a sample of missions and means. Parks and Recreation, 4.

3. Bauer R. (1959). The sociology of leisure time. Transactions of the Fourth World Congress of Sociology, 2.

4. Chick, G. (1998). Science, materialism and the quest for anthropology of leisure: a rejoinder. Leisure sciences, 20 (3).

5. Coalter, F. (1997). Leisure science and leisure studies: different concept, same crisis? Leisure sciences, 19 (4).

6. Doronkina, E. G. (1999). Problema professionalnoi podgotovki kadrov dlia sfery dosuga: zarubezhnyi opyt. Moscow: MGUKI.

7. Kiseleva, T. G., \& Chizhikov, V. M. (2000). Spetsialist kultury i dosuga novogo tysiacheletiia: materialy "kruglogo stola". Moscow: MGUKI. 
sciendo Порівняльна професійна педагогіка 8(4)/2018 Comparative Professional Pedagogy 8(4)/2018

8. Mandi, S. (2002). Obrazovanie i professionalnaia podgotovka. Kulturnaia politika v Evrope: vybor strategii i orientiry. Moscow: Izdatelstvo Libereia.

9. McCall, M. W., Jr., Lombardo, M. M., \& Morrison, A. M. (1988). The lessons of experience: How successful executives develop on the job. New York, NY: The Free Press.

10. McCauley, C. D., \& Brutus, S. (1998). Management development through job experiences. Greensboro, NCL: Center for Creative Leadership.

11. McKnight, G. H., Cummings, L. L., \& Cervany, N. L. (1998). Initial trust formation in new organizational relationships. Academy of Management Review, 23, 473-490.

12. Merton, R. (1948). The self-fulfilling prophecy. Antioch Review, 9, 193-210.

13. Mullins, L. (2007). Management and organizational behaviour. Edinburgh: Financial Times Prentice Hall.

14. Peterson, D. B. (1996). Executive coaching at work: The art of one-on-one change. Consulting Psychology Journal: Practice and Research, 48, 78-86.

15. Petrova, I. V. (2005). Dozvillia u zarubizhnykh krainakh. Kyiv: Kondor.

16. Pichkar, O. P. (2002). Systema pidhotovky fakhivtsiv sotsialnoi roboty u Velykii Brytanii. (Avtoref. dys. kand. ped. nauk). Ternopilskyi derzhavnyi pedahohichnyi universytet im. V. Hnatiuka, Ternopil.

17. Riggio, R. E. (2008). Leadership Development: the current state and future expectations. Consulting Psychology Journal: Practice and Research, 3, 383-392.

18. Seifert, C. F., McDonald, R. A., \& Yukl, G. (2003). Effects of Multisource Feedback and a Feedback Facilitator on the Influence Behaviour of Managers toward Subordinates. Journal of Applied Psychology, 88 (3), 561-569.

19. Shala, A., \& Grajcevci, A. (2017). Digital competencies among students' populations in Kosovo: the impact of inclusion, socioeconomic status, ethnicity and type of residence.

20. Slozanska, A. (n.a.). Sotsialnyi pedahoh yak orhanizator osvitno- dozvillievoi diialnosti pidlitkiv. Vziato z http://www.academia.edu/9191178/Sotsialnyi_pedahoh_iak _orh.

21. Smither, J. W., London, M., \& Reilly, R. R. (2005a). Does Performance Improve Following Multisource Feedback? A Theoretical Model, Meta-Analysis, and Review of Empirical Findings. Personal Psychology, 55, 33-66.

22. Smither, J. W., London, M., \& Richmond, K. R. (2005b). Relationships between leaders' personality and reactions to, and use of, multisource feedback: A longitude study. Group and Organizational Management, 30 (2), 181-210.

23. Streltsov, Yu. A. (2002). Kulturologiia dosuga. Moskva: MGUK.

24. Torkildsen, G. (1983). Leisure and recreation management. London: E. \& F. N. Spon.

25. Yammarino, F., \& Atwater, L. (1993). Understanding self-perception accuracy: Implications for human resource management. Human Resources Management, 32, 231-247.

26. Yukl, G. (2006). Leadership in Organizations. Upper Saddle River: Pearson Prentice Hall. 